This item was submitted to Loughborough's Research Repository by the author.

Items in Figshare are protected by copyright, with all rights reserved, unless otherwise indicated.

\title{
Using functional resonance analysis method to understand construction activities for concrete structures
}

PLEASE CITE THE PUBLISHED VERSION

https://doi.org/10.1016/j.ssci.2020.104771

PUBLISHER

Elsevier BV

VERSION

AM (Accepted Manuscript)

\section{PUBLISHER STATEMENT}

This paper was accepted for publication in the journal Safety Science and the definitive published version is available at https://doi.org/10.1016/j.ssci.2020.104771

\section{LICENCE}

CC BY-NC-ND 4.0

\section{REPOSITORY RECORD}

del Carmen Pardo-Ferreira, María, Juan Carlos Rubio-Romero, Alistair Gibb, and Santiago Calero-Castro. 2020. "Using Functional Resonance Analysis Method to Understand Construction Activities for Concrete Structures". figshare. https://hdl.handle.net/2134/12176763.v1. 


\title{
Using Functional Resonance Analysis Method to understand construction activities for concrete structures
}

\begin{abstract}
The improvement of safety management in the construction sector, especially in activities for concrete structures, continues to be necessary. This paper aims at increasing understanding of everyday construction activities for building concrete structures in order to improve resilient safety management. The Functional Resonance Analysis Method (FRAM) has been applied to these activities for this purpose. Analysis of available documentation, on-site interviews and observations have been conducted to collect data. The FRAM analysis revealed that the construction phase health and safety plan is rarely used, that organizational pressure affects safety and that leading indicators to monitor normal work are not used. In addition, delivery of concrete on site and crane operations as key factors due to their influence on variability. This study outlined the potential of the FRAM model as the basis of in-depth and systematic analysis of daily performance, highlighting issues that, until now, had been undervalued.
\end{abstract}

KEYWORDS: FRAM, Resilience Engineering, Safety-II, construction, concrete structure

\section{HIGHLIGHTS:}

- The study aims to understand performance variability in construction activities

- FRAM was applied to the construction activities of reinforced concrete building structures

- FRAM highlights issues that until now had been undervalued

- Safety-II could help to improve safety management in construction activities

\section{Introduction}

The construction sector continues to have high accident rates. According to the Annual Report on Occupational accidents in Spain, published by the National Institute of Occupational Safety and Health in 2016, the construction sector had the highest accident rate, over twice the average registered in the rest of industry (INSSBT, 2017). The global picture is similar. In Europe, over one fifth of deaths due to occupational accidents occurred in the construction sector (Eurostat, 2018). In the US, figures are identical. According to the Occupational Health and Safety Administration, one in every five deaths of workers in 2016 occurred in the construction sector (OSHA, 2018). Based on this data, there is a continuing need for improved safety management in construction. The highest accident ratios are registered in the construction of concrete formwork structures (Bilir and Gürcanli, 2018; Hallowell and Gambatese, 2009; López-Arquillos et al., 2015). Therefore, further research on safety in the performance of these activities is beneficial.

It must be considered that safety management in construction, as in many other sectors, has been based, for a long time, on linear models of causality. Currently, these models 
do not adapt to the reality of increasingly complex and coupled organizations that have become complex socio-technical systems. This leads to the use of systemic models along with Resilience Engineering (RE) as a new "paradigm of safety management focused on how to help people to successfully deal with complex situations under pressure" (Woods and Hollnagel, 2006).

Resilience Management serves as a breakaway from the traditional idea of safety to introduce a proactive approach focused on everyday performance. Leading researcher Erik Hollnagel has called this Safety-II (Hollnagel, 2014). In this way, the term Safety-I is used to refer to the traditional concept of Safety, that is, a reactive safety focused on the study of things that go wrong as failures, incidents or accidents through causal relationships. Safety-II goes one step further by proposing a proactive approach to safety focused on studying the things that go well and daily success through non-linear and complex relationships. RE also marks a difference between work-as-imaged, or rather, the previous concept of how the work should be performed, and the work-as-done concept, which is the usual day-to-day working methods. This difference stems from the fact that reality is complex, variable and even unpredictable and working conditions are rarely ideal. Therefore, the procedures and instructions are incomplete and inaccurate (Clay-Williams et al., 2015). Resources and time are also limited and organisational, economic, social and other types of pressure is felt. In order to achieve success in daily work, adjustments must be made, which are habitual rather than exceptional, to match working conditions and the expected outcome. In other words, people make adjustments to achieve acceptable outcomes under existing circumstances. For this purpose, a balance between efficiency and thoroughness, known as Efficiency Thoroughness Trade Off (ETTO) principle, is constantly being carried out (Hollnagel, 2009).

Based on the above, safety can be defined as a quality "to make dynamic trade-offs and to adjust performance in order to meet changing demands and to deal with disturbances and surprises" (Sujan et al., 2017). Therefore, adjustments are a sine qua non condition. These adjustments can be made due to variability that therefore becomes the basis for success. Thus, variability must be seen as something necessary for system operation and should not be constrained; it should simply be understood and dampened (Hollnagel, 2012; Rubio-Romero et al., 2019).

In this context, the Functional Resonance Analysis Method (FRAM) appears to be a key tool for understanding how variability spreads through a system. That is, how, by these approximate adjustments, it is possible to dampen variability, keep it within proper performance limits and see how it increases in an unusual way giving rise to functional resonance. FRAM-related activities aim to provide an understanding of how the system really works in order to improve its capacity and adapt it to unforeseen circumstances without exceeding variability limits. FRAM defines complex systems based on the functions or tasks performed in these systems to achieve a specific goal, not on how they are structured or on the parts that compose them. System limits are defined in a description of its functions. Focus should now be on analysing variability in order to understand where it comes from and how it is spread through the system with couplings between these functions. The measures obtained as a result of the FRAM analysis should then be focused on the proper management and handling of variability during performance to prevent functional resonance. Therefore, FRAM can be defined as a qualitative method of RE used to help us understand how work-as-done is implemented in complex socio-technical systems. 
Construction work in general and structures in particular have the necessary characteristics (Badham and Clegg, 2000; Baxter and Sommerville, 2011) to qualify them as complex socio-technical systems, as they comprise technical and social subsystems, are strongly influenced by the external environment and have a large number of separate agents that are interrelated in a complex manner. Consequently, if we want to improve safety management in these activities, the issue cannot be addressed through traditional models and methods. The systemic vision of RE and FRAM can provide a suitable path to achieve this improvement.

\subsection{Resilience Engineering (RE) and the construction sector}

Up until now, most of the research developed on RE has focused on two aspects: the theoretical side and its application to high-risk and complex sectors like air traffic, as well as health, the chemical and petrochemical industry, nuclear power stations, rail or sea traffic, etc. In the construction sector, work found in this area is scarce and it is all usually focused on theory or the development of safety management tools (Righi et al., 2015).

Research focused on RE and the construction sector highlights Tarcisio Abreu Saurin as one of the most prolific authors. Along with others, he has conducted several studies that analyse the implementation of good safety management practices in construction (Saurin et al., 2008), definition of design criteria and evaluation of performance measurement systems (Saurin et al., 2014, 2013) or comparison of RE and Lean Construction perspectives applied to construction activities (Saurin and Sanches, 2014).

There are also studies on RE and the construction sector that focus on the application of the FRAM analysis to different construction activities like waste recycling (Haddad and Rosa, 2015; Rosa et al., 2017, 2015), crane operations (Von Buren, 2013), safety inspections (Saurin, 2016) or tunnelling operations (Schafer et al., 2009).

Nevertheless, empirical studies focused on construction and RE are still scarce (Pillay, 2017). Therefore, the application of RE to the construction sector is one of the major challenges found in research in this field (Harvey et al., 2016; Pillay, 2017; Righi et al., 2015; Saurin et al., 2008).

This study is therefore aimed at increasing the application of RE to construction using FRAM technology. More specifically, the purpose of this study is to find out how concrete structures are usually built and propose actions or measures to increase safety in these operations by focusing on RE. Therefore, FRAM was applied to enable a systematic and qualitative analysis to be performed on the operation of a system or organization.

In the next section, the research method is presented including data collection, participants and a description of FRAM. Section 3 describes the results obtained in each of the FRAM stages. Section 4 includes a methodological discussion about FRAM focused on the main advantages and disadvantages found during the development of the application case. Section 5 proposes future research lines. To conclude, Section 6 presents the main findings of this study. 


\section{Methodology}

\subsection{Data collection}

Data is collected during the main tasks: analysis of available documentation and fieldwork based on interviews and observations that will be explained in further detail below. The analysis of the documentation included a review of the regulations in force, guidance manuals and other available information on building structures. Safety and health plans for construction sites that were going to be visited were also analysed. The aim of this analysis was to learn about "work-as-imagined".

Fieldwork was subsequently geared towards learning about "work-as-done". Three construction companies cooperated in the research. 33 visits were made in seven months to five construction sites in the province of Málaga, Spain, all of which were in the structure construction phase. During these visits, work was observed and workers interviewed. Table 1 contains a summary of the main characteristics of these works including the number of visits and interviews that took place at each one.

\begin{tabular}{|c|c|c|c|c|c|c|}
\hline $\begin{array}{l}\text { Company I } \\
\text { Construction } \\
\text { site }\end{array}$ & No. of building floors & $\begin{array}{l}\text { Material } \\
\text { execution } \\
\text { budget }\end{array}$ & $\begin{array}{l}\text { Safety and } \\
\text { health } \\
\text { budget }\end{array}$ & $\begin{array}{c}\text { Execution } \\
\text { time }\end{array}$ & $\begin{array}{c}\text { No. of } \\
\text { workers in } \\
\text { the } \\
\text { construction } \\
\text { site }\end{array}$ & $\begin{array}{c}\text { No. of } \\
\text { visits and } \\
\text { interviews }\end{array}$ \\
\hline $\begin{array}{c}\text { Bloques } \\
\text { Company } 1 \text { / } \\
\text { Construction } \\
\text { site } 1\end{array}$ & $\begin{array}{c}2 \text { Buildings, each one } \\
\text { with } 2 \text { basement floors } \\
+1 \text { commercial floor } \\
+7 \text { housing floors } \\
\text { (135 flats) }\end{array}$ & $11.544 .691 €$ & $160.580 €$ & 20 months & $\begin{array}{c}65 \text { workers } \\
\text { on average } \\
\text { and a peak of } \\
128 \text { workers }\end{array}$ & $\begin{array}{c}14 \text { visits } \\
\text { and } 27 \\
\text { interviews }\end{array}$ \\
\hline $\begin{array}{c}\text { Company } 1 \text { I } \\
\text { Construction } \\
\text { site } 2\end{array}$ & $\begin{array}{c}6 \text { Multifamiliar buildings } \\
\text { with } 1 \text { basement floor } \\
+3 \text { housing floors } \\
\text { (72 flats) }\end{array}$ & $9.934 .987 €$ & $118.221 €$ & 18 months & $\begin{array}{c}45 \text { workers } \\
\text { on average } \\
\text { and a peak of } \\
90 \text { workers }\end{array}$ & $\begin{array}{l}3 \text { visits and } \\
9 \text { interviews }\end{array}$ \\
\hline $\begin{array}{c}\text { Company } 1 \text { I } \\
\text { Construction } \\
\text { site } 3\end{array}$ & $\begin{array}{c}4 \text { Buildings with } \\
1 \text { basement floor } \\
+3 \text { housing floors } \\
\text { (47 flats) }\end{array}$ & $5.866 .157 €$ & $89.728 €$ & 15 months & $\begin{array}{l}44 \text { workers } \\
\text { on average } \\
\text { and a peak of } \\
100 \text { workers }\end{array}$ & $\begin{array}{c}3 \text { visits and } \\
11 \\
\text { interviews }\end{array}$ \\
\hline $\begin{array}{c}\text { Company } 21 \\
\text { Construction } \\
\text { site } 4\end{array}$ & $\begin{array}{c}1 \text { Building with } \\
3 \text { basement floors } \\
+1 \text { commercial floor } \\
+10 \text { housing floors } \\
\text { (110 flats })\end{array}$ & $8.084 .490 €$ & $207.771 €$ & 24 months & $\begin{array}{l}30 \text { workers } \\
\text { on average } \\
\text { and a peak of } \\
50 \text { workers }\end{array}$ & $\begin{array}{c}10 \text { visits } \\
\text { and } 23 \\
\text { interviews }\end{array}$ \\
\hline $\begin{array}{l}\text { Company } 31 \\
\text { Construction } \\
\text { site } 5\end{array}$ & $\begin{array}{l}1 \text { Building with } \\
4 \text { floors }\end{array}$ & $4.841 .614 €$ & $47.894 €$ & 16 months & $\begin{array}{c}25 \text { workers } \\
\text { on average } \\
\text { and a peak of } \\
42 \text { workers }\end{array}$ & $\begin{array}{c}3 \text { visits and } \\
15 \\
\text { interviews }\end{array}$ \\
\hline
\end{tabular}

Table 1. Characteristics of the sites visited during fieldwork

\subsubsection{Semi-structured interviews}

During site visits a total of 85 interviews were conducted and recorded with the interviewee's knowledge and consent. The average duration of the interviews was 10 minutes, ranging from three to 50 minutes and a total time of 864 minutes. A template containing questions was designed beforehand as a guide for the semi-structured interviews. The first part of the template included questions on demographic information from workers and the second part contained open questions so that the workers could describe their daily work in their own words. Different FRAM publications were used to 
prepare these questions, which included guidelines or examples of questions for collecting data (Albery et al., 2016; Clay-Williams et al., 2015; Hollnagel et al., 2014; Pickup et al., 2017; Studic, 2015).

\subsubsection{Open-ended observations}

On-site construction of concrete structures was also observed during the site visits. These observations were documented with photographs that complemented the information obtained in the interviews. During the observations, informal conversations were held with the supervisor or other workers to comment briefly on the work being observed. The objective of the observations was to complete the data collected through interviews to make it easier to understand the tasks that would be subsequently analysed with FRAM.

\subsection{Participants}

The 85 workers who participated performed different jobs involved in building concrete structures (Table 2). According to Hollnagel et al. (2014), the best source of information for collecting data are the workers performing the activities being studied. This is why only one construction manager and one site supervisor were interviewed. Other workers interviewed were responsible for building the structure. All workers were men of an average age of 43 with an average of 16.7 years' experience in structural work. These workers were also employed by different subcontractors or even the main contractor. This is typical of construction projects and is one of the factors that makes work organisation and safety management even more complex (Gibb et al., 2016).

\begin{tabular}{|l|c|}
\hline \multicolumn{1}{|c|}{ Job } & Number of interviews conducted \\
\hline Construction manager & 1 \\
\hline Site Supervisor & 1 \\
\hline Foreman of formworks operators & 4 \\
\hline Formwork operator & 36 \\
\hline Foreman of rebar operators & 2 \\
\hline Rebar operator & 24 \\
\hline Safety staff & 12 \\
\hline Operator for stakeout & 2 \\
\hline Crane operator & 2 \\
\hline Concrete pump operator & 1 \\
\hline TOTAL & $\mathbf{8 5}$ \\
\hline
\end{tabular}

Table 2. Distribution of interviews conducted per workplace

\subsection{Functional Resonance Analysis Method (FRAM)}

The Functional Resonance Analysis Method (FRAM) was applied following the procedures established by Hollnagel (2012) shown in Figure 1. Step zero focused on defining the objective and scope of the FRAM analysis. This was the only step taken prior to data collection. 


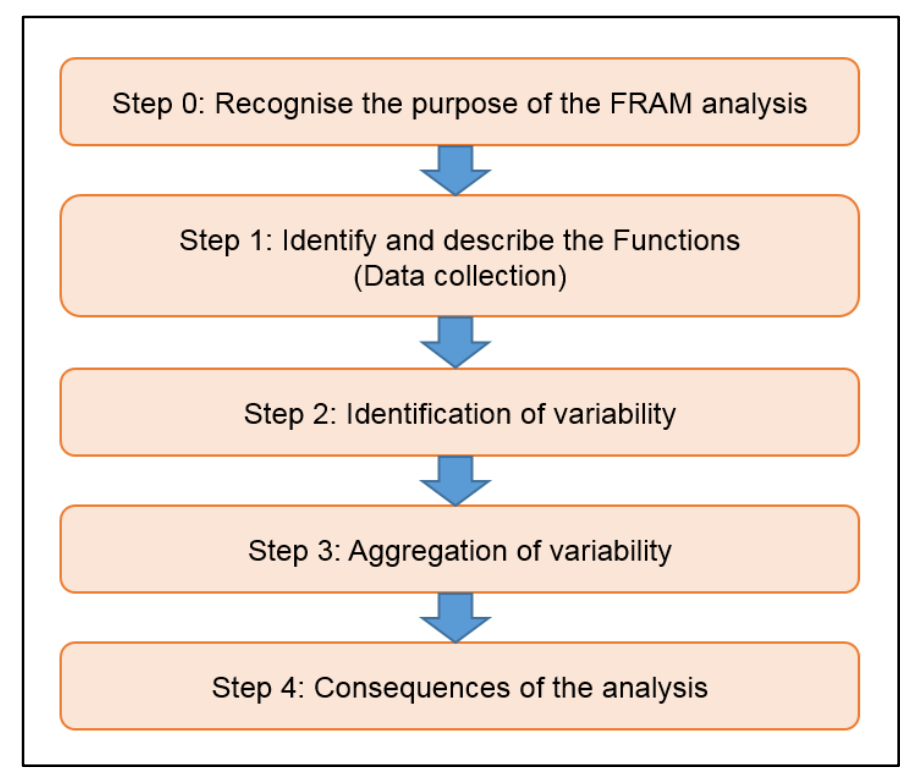

Figure 1. Steps to apply the FRAM method

After collecting all information, the first step was taken in the method focused on identifying and describing functions. A function is a task or activity performed in a system. Each function comprising the model was briefly described and its six aspects identified (input, output, precondition, resource, control, time). The result was the FRAM model, using FRAM Model Visualiser (FMV) version 0.4.1. Before moving on to the next step, the draft model was revised in two successive meetings with two safety and construction experts.

Then the second step was taken, focusing on analysing variability. The variability of each function was therefore analysed individually. To do this, internal and external variability sources were identified that could influence the variability of the model's functions. The variability of each function was also specifically analysed in terms of time and precision.

The third step focused on the aggregation of variability, meaning that variability would be analysed again but this time all functions of the model as a whole would be taken into account. The aim of this was to analyse how variability can be spread by couplings between functions upstream and downstream and be increased or dampened through the system. This propagation of variability between functions could affect system results. To carry out this analysis, the actual couplings are analysed in specific conditions, which is known as instantiation. Different instantiations can be considered in a model.

Finally, the fourth step focuses on extracting the main conclusions of the FRAM analysis performed. These conclusions could help to identify the system's critical points where variability could cause functional resonance and establish measures to control and dampen this variability, thus making the system more resilient. 


\begin{tabular}{|c|c|c|c|c|c|}
\hline Formwork & Rebar & Concreting & $\begin{array}{l}\text { Setting out and } \\
\text { verifications }\end{array}$ & $\begin{array}{l}\text { Collective or individual } \\
\text { protections }\end{array}$ & $\begin{array}{c}\text { Transportation of items with } \\
\text { crane }\end{array}$ \\
\hline $\begin{array}{c}\text { To place the plastic circular } \\
\text { spacers }\end{array}$ & $\begin{array}{l}\text { To manufacture the } \\
\text { rebar cage }\end{array}$ & $\begin{array}{c}\text { To pour the concrete for the } \\
\text { columns or walls }\end{array}$ & $\begin{array}{c}\text { To set out the } \\
\text { columns }\end{array}$ & To assemble safety lifeline & $\begin{array}{c}\text { To decide what to transport with the } \\
\text { crane }\end{array}$ \\
\hline To prepare formwork panels & $\begin{array}{l}\text { To manufacture the } \\
\text { rebar walls }\end{array}$ & To place concrete vibrator & $\begin{array}{l}\text { To set out the } \\
\text { rebar for slab }\end{array}$ & $\begin{array}{c}\text { To assemble safety nets } \\
\text { under slab }\end{array}$ & $\begin{array}{c}\text { To store materials and other } \\
\text { resources }\end{array}$ \\
\hline To place the formwork panels & $\begin{array}{l}\text { To place the rebar } \\
\text { cage }\end{array}$ & $\begin{array}{c}\text { To vibrate the concrete of the } \\
\text { columns or walls }\end{array}$ & $\begin{array}{l}\text { To check the } \\
\text { rebar }\end{array}$ & To assemble nets in the hole & $\begin{array}{l}\text { To transport items for their } \\
\text { assembly or disassembly on site }\end{array}$ \\
\hline $\begin{array}{l}\text { To plumb and brace the } \\
\text { formwork for the columns and } \\
\text { walls }\end{array}$ & $\begin{array}{l}\text { To bend the ends of } \\
\text { the rebar cage }\end{array}$ & To fill the concrete skip & $\begin{array}{l}\text { To develop the } \\
\text { building project }\end{array}$ & $\begin{array}{l}\text { To assemble handrails on } \\
\text { slab formwork }\end{array}$ & $\begin{array}{c}\text { To coordinate with the crane } \\
\text { operator }\end{array}$ \\
\hline $\begin{array}{l}\text { To remove the formwork of } \\
\text { the columns and walls }\end{array}$ & $\begin{array}{l}\text { To install the rebar } \\
\text { for slab }\end{array}$ & $\begin{array}{c}\text { To let the concrete of the columns } \\
\text { and walls cure }\end{array}$ & & $\begin{array}{c}\text { To install type } V \text { safety net } \\
\text { system }\end{array}$ & $\begin{array}{l}\text { To have experience in crane } \\
\text { handling and know the tasks for the } \\
\text { building structure construction }\end{array}$ \\
\hline $\begin{array}{l}\text { To decide to start the } \\
\text { assembly of slab formwork }\end{array}$ & $\begin{array}{l}\text { To add the missing } \\
\text { reinforcement steel }\end{array}$ & To pour the concrete of the slab & & $\begin{array}{c}\text { To assemble vertical safety } \\
\text { nets }\end{array}$ & To test the crane \\
\hline $\begin{array}{c}\begin{array}{c}\text { To assemble the slab } \\
\text { formwork }\end{array} \\
\end{array}$ & $\begin{array}{c}\text { To install the rebar } \\
\text { for stairs }\end{array}$ & To vibrate the concrete of the slab & & To perform load test & \\
\hline $\begin{array}{c}\text { To decide to start the } \\
\text { placement of boards and riser }\end{array}$ & & To smooth the concrete surface & & To disassemble safety line & \\
\hline To place boards and risers & & To order the concrete & & $\begin{array}{l}\text { To place elements for } \\
\text { collective protections }\end{array}$ & \\
\hline $\begin{array}{c}\text { To cover gaps between } \\
\text { boards }\end{array}$ & & $\begin{array}{l}\text { To receive the concrete delivered } \\
\text { on site }\end{array}$ & & $\begin{array}{l}\text { To disassemble handrails } \\
\text { from the slab formwork }\end{array}$ & \\
\hline $\begin{array}{l}\text { To partially remove the slab } \\
\text { formwork }\end{array}$ & & $\begin{array}{l}\text { To have experience to foresee the } \\
\text { evolution of the works }\end{array}$ & & $\begin{array}{l}\text { To assemble handrails on } \\
\text { slab }\end{array}$ & \\
\hline $\begin{array}{c}\text { To completely remove the } \\
\text { slab formwork }\end{array}$ & & $\begin{array}{l}\text { To position the concrete mixer truck } \\
\text { for the pouring }\end{array}$ & & $\begin{array}{c}\text { To disassemble safety nets } \\
\text { under slab }\end{array}$ & \\
\hline $\begin{array}{l}\text { To have adequate experience } \\
\text { to decide the execution of } \\
\text { works }\end{array}$ & & $\begin{array}{c}\text { To have a pump truck for the } \\
\text { dumping }\end{array}$ & & $\begin{array}{l}\text { To hire safety staff for the } \\
\text { construction site }\end{array}$ & \\
\hline $\begin{array}{c}\text { To assemble formwork for } \\
\text { stairs }\end{array}$ & & To pour concrete in the truck pump & & $\begin{array}{c}\text { To place rebar protection } \\
\text { caps }\end{array}$ & \\
\hline \multirow[t]{4}{*}{$\begin{array}{c}\text { To disassemble formwork for } \\
\text { stairs }\end{array}$} & & To let the slab concrete cure & & & \\
\hline & & $\begin{array}{c}\text { To take concrete samples for quality } \\
\text { control }\end{array}$ & & & \\
\hline & & To test the quality of the concrete & & & \\
\hline & & To let the slab concrete set & & & \\
\hline
\end{tabular}

Table 3. Functions of the FRAM model grouped together according to activity 


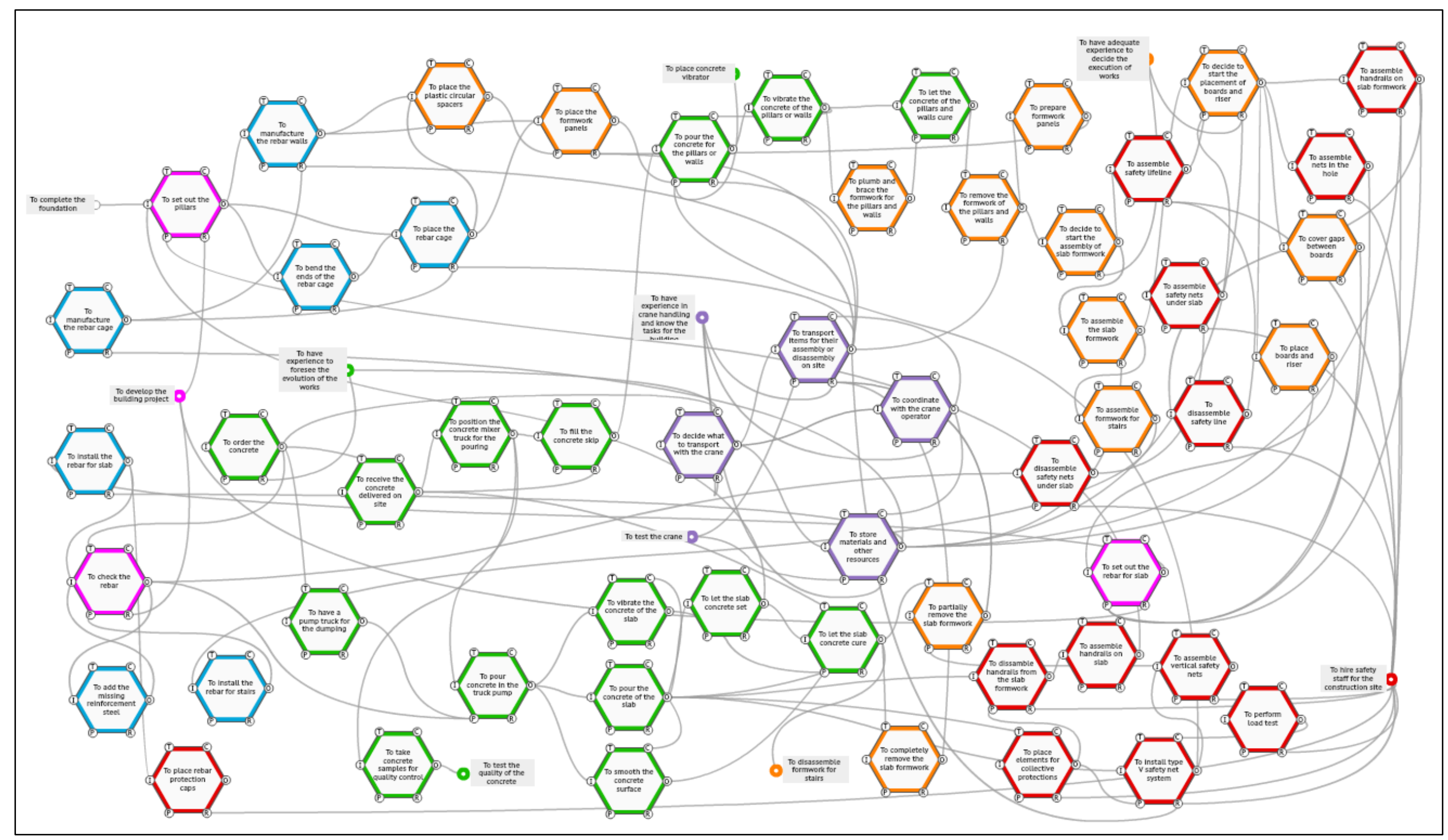

Figure 2. FRAM model of tasks involved in the construction of a concrete structure of a building. 


\section{Results}

\subsection{Step 0: Recognise the purpose of the FRAM analysis}

As mentioned in the introduction, the aim was to know how everyday work is carried out in the construction of a concrete frame or structure of a building. Thus, a prospective analysis was conducted. Specifically, the present study focused on everyday performance of activities from the foundations to the structure of a building. The type of slab analysed was a solid concrete slab manufactured on site. In addition, the building once built would have residential use and would not present overhangs or other special structures. Once built, the building would also be for residential use and would not have cantilevers or other special structural features.

\subsection{Step 1: Identify and describe the Functions}

The proposed FRAM model encompassed a total of 65 functions. Different types of work and activities are involved in building a structure. Therefore, the functions of the FRAM were organised into 6 groups. Each group contributed to the construction process with major or relevant activities like formwork, steelwork, concreting, setting out and verifications, material transport with the tower crane and assembly/disassembly of collective or individual protections. A colour was assigned to each group of activities or functions as shown in the first row of Table 3. This table shows the functions of each group of activities with the exception of completion of the foundations, which is a background function, as the construction processes prior to starting to build the structure are beyond the scope of the model performed. Once all functions were identified, the FRAM model shown in Figure 2 was obtained.

\subsection{Step 2: Identification of variability}

The majority of the functions identified in the previous step were human actions. These functions are characterised by their high variability. Amongst the external variability sources that might affect the performance of the functions are extreme weather conditions and rain. On-site construction work is performed outdoors and the variability in its performance by workers can be significantly affected. In fact, this could affect the whole organisation, as on-site work comes to a standstill in adverse weather conditions. In the event of heavy rain or winds, environmental operating conditions can also exceed the design specifications for the crane. In such cases, it must no longer be used.

Pouring the concrete floor itself could also be an external source of variability, mainly due to its incapacity to meet the existing demand. Delayed deliveries of concrete delays performance of the work, meaning that the workload could increase and require workers to do overtime to compensate them. Changes to the work plan may also take place.

On the other hand, there is pressure to perform the work in the time required by the main contractor. This economic pressure is due to the project delivery date agreed upon between the main contractor and developer. Normally, contracts cover compensation of large amounts of money payable by the contractor to the developer for each day of delay. The public authorities may also increase pressure due to the delay in granting the 
necessary licenses to start work as, in such cases, the delivery date is usually maintained.

Internal variability, on the other hand, is a common situation on construction sites as workers are exposed to a high workload, long work hours and deadline pressures. These could cause stress and fatigue and affect workers' mental capacities. This type of work also involves high physical strain. Variability can also be psychological like in decisionmaking, level of experience or qualifications to perform tasks.

It must also be taken into account that organisational safety culture affects variability. Workers responsible for assembly / disassembly of collective or individual protections at the site, for example, reported in the interviews that it is normal procedure for other workers to dismantle guardrails to perform certain tasks without putting them back in place. One of these workers said: "the most common problem is that they remove the guardrails, or rather, what you put up, they take away, which is totally forbidden but people don't take any notice. What you put up, the next day you get there and it has been removed". It should be added that it is a common occurrence for the installation of collective or individual protections and their maintenance to be subcontracted by the main contractor and for workers assigned to this task to be scarce.

Internal variability could also be considered due to lack of maintenance of machinery used for building structures, mainly the tower crane.

After identifying sources of variability, a study was conducted on the variability of each individual function in terms of timing and precision. Table 4 identifies the variability of the function "order concrete", for example. The supervisor must decide on the amount, type and date of delivery of the concrete to the site. Any deviation from this decision can cause the function to show output variability.

\begin{tabular}{|l|l|l|l|}
\hline & \multicolumn{3}{|c|}{ To order the concrete } \\
\hline
\end{tabular}

Table 4. Identification of the variability of the function "order concrete"

\subsection{Step 3: Aggregation of variability}

The normal procedure for analysing propagation of variability up and downstream is to analyse instantiations of the model, that is, a specific case or scenario. However, as other authors have done previously (Praetorius et al., 2015; Raben et al., 2018a), and in 
line with the objective of this study, this step will contain an analysis of how variability could spread and cause functional resonance in everyday operations. For this purpose, we studied how changes affect each of the functions and aspects of the variability model (Raben et al., 2018a). As a result, some functions of special interest were found due to their eventual influence on others in the model. The variability of these functions might spread and increase through the rest of the model, affecting system performance. Consequently, functional resonance may appear that could lead to adverse or unwanted outcomes. These functions are listed here and analysed in the following paragraph:

- "To order concrete"

- "To decide which elements to transport with the tower crane"

- Set of functions focused on the assembly of collective or individual protections

The function "order the concrete" has a large impact on the way in which the other functions of the model are performed. Normally, the concrete is ordered in a week or so before its delivery to the site, depending on the volume of orders at the plant where the concrete is ordered and the amount of concrete required. On the day agreed on for delivery of the concrete to the site, all previous work necessary for being able to pour the concrete must have been completed. Therefore, if the date for delivering the concrete to the site is too soon, or if concrete is scheduled to be delivered before work is completed, then this causes internal variability in the function that is spread through the FRAM model. This is due to the fact that verification that the concrete pour will proceed and notice to the concrete supplier must take place the day before delivery of the concrete to the site. For this purpose, all functions upstream of "check the floor structure" must be completed on time before that date. When workers were asked how the delivery date of the concrete affected their work, one of the steel workers said: "We have to comply with a deadline. We are the ones who rush the most: "Hey, tomorrow we have to lay concrete. Do everything you can to finish". This often leads to compensation (ETTO principle) in the way in which these functions are performed. Workers must take less care in their work to achieve their goals and have everything prepared for the delivery of the concrete. To achieve this goal, they take short cuts and omit parts of the process that are not strictly necessary. Consequently, carefulness is sacrificed in favour of efficiency and the problem is that if the sacrifice is large, safety can be compromised.

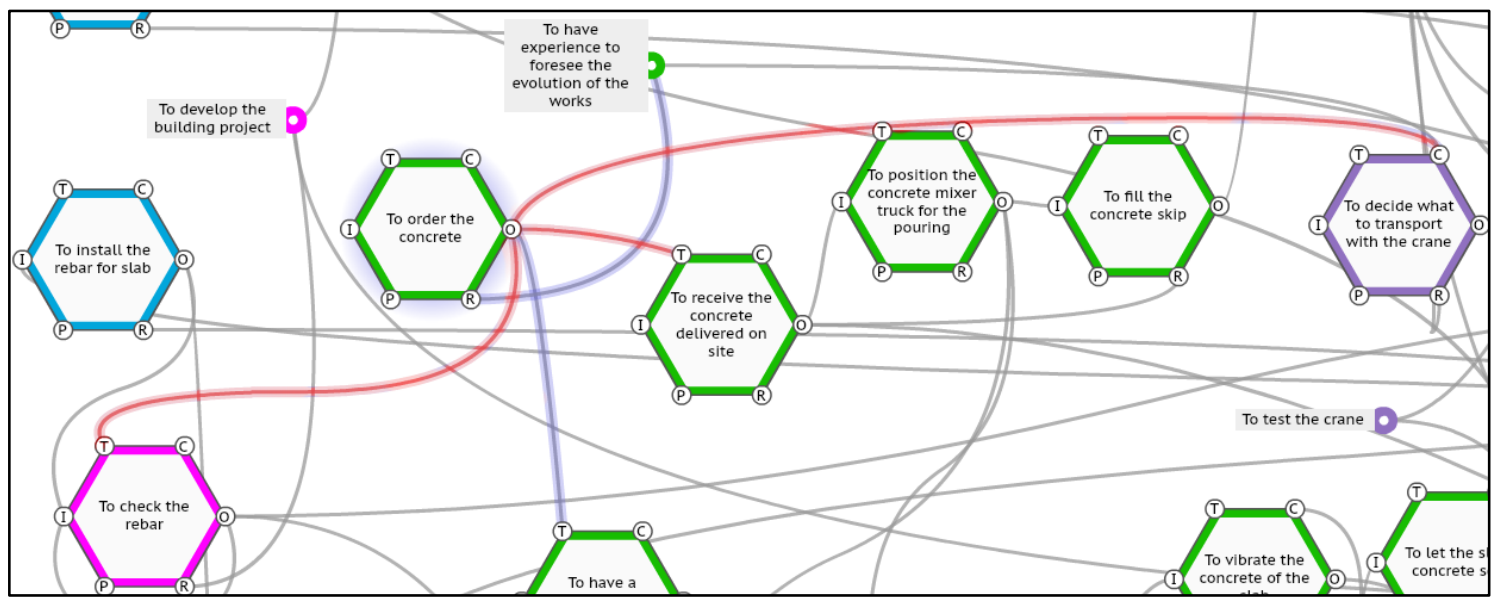

Figure 1. Couplings downstream of the function "order the concrete" 


\begin{tabular}{|c|c|c|c|c|c|c|}
\hline Function & $\begin{array}{l}\text { Output of the } \\
\text { function }\end{array}$ & $\begin{array}{l}\text { Aspect of the } \\
\text { downstream } \\
\text { function }\end{array}$ & $\begin{array}{l}\text { Downstream } \\
\text { function }\end{array}$ & $\begin{array}{l}\text { Output of the } \\
\text { downstream } \\
\text { function }\end{array}$ & $\begin{array}{l}\text { Aspect of the } \\
\text { next function } \\
\text { downstream }\end{array}$ & Next function downstream \\
\hline \multirow{17}{*}{$\begin{array}{l}\text { To decide } \\
\text { what to } \\
\text { transport } \\
\text { with the } \\
\text { crane }\end{array}$} & \multirow{9}{*}{$\begin{array}{l}\text { Decision to } \\
\text { transport } \\
\text { materials and } \\
\text { other } \\
\text { resources for } \\
\text { storage }\end{array}$} & \multirow{9}{*}{ Input } & \multirow{7}{*}{$\begin{array}{l}\text { To store materials } \\
\text { and other } \\
\text { resources }\end{array}$} & \multirow{7}{*}{ Stored materials } & Resource & To manufacture the rebar cage \\
\hline & & & & & Resource & To assemble the slab formwork \\
\hline & & & & & Resource & To place boards and riser \\
\hline & & & & & Resource & To assemble handrails on the slab formwork \\
\hline & & & & & Resource & To assemble handrails on the slab \\
\hline & & & & & Resource & To install the rebar for slab \\
\hline & & & & & Resource & To decide to start the placement of boards and riser \\
\hline & & & \multirow{2}{*}{$\begin{array}{l}\text { To coordinate with } \\
\text { the crane } \\
\text { operator* }^{*}\end{array}$} & \multirow{2}{*}{$\begin{array}{l}\text { Coordination } \\
\text { with the crane } \\
\text { operator }\end{array}$} & Control & To store materials and other resources* \\
\hline & & & & & Control & To transport items for their assembly or dismantling on site* \\
\hline & \multirow{8}{*}{$\begin{array}{l}\text { Decision to } \\
\text { transport } \\
\text { items for } \\
\text { assembly or } \\
\text { disassembly } \\
\text { on site }\end{array}$} & \multirow{8}{*}{ Input } & \multirow{6}{*}{$\begin{array}{l}\text { To transport items } \\
\text { for their assembly } \\
\text { or disassembly on } \\
\text { site }\end{array}$} & \multirow{6}{*}{$\begin{array}{l}\text { Elements ready } \\
\text { for assembly or } \\
\text { disassembly }\end{array}$} & Resource & To install rebar cage of the columns \\
\hline & & & & & Resource & To install rebar cage of the walls \\
\hline & & & & & Resource & To place formwork panels \\
\hline & & & & & Resource & To pour the concrete for the columns or walls \\
\hline & & & & & Resource & To remove formwork of the columns and walls \\
\hline & & & & & Resource & To install type $V$ safety net system \\
\hline & & & \multirow{2}{*}{$\begin{array}{l}\text { To coordinate with } \\
\text { the crane } \\
\text { operator* }\end{array}$} & \multirow{2}{*}{$\begin{array}{l}\text { Coordination } \\
\text { with the crane } \\
\text { operator }\end{array}$} & Control & To store materials and other resources* \\
\hline & & & & & Control & To transport items for their assembly or dismantling on site* \\
\hline
\end{tabular}

* The function <Coordinate with the crane operator> has two inputs that activate it which are the outputs of the function <To decide what to transport with the tower crane>, so that is why it is repeated in the table. Its output "Coordination with the crane operator" is connected through control with the two functions $<$ To store materials and other resources $>$ and $<$ To transport items for their assembly or dismantling on site>. Therefore, whenever the function <To decide what to transport with the tower crane $>$ is activated, regardless of the resulting output, the function $<$ To coordinate with the crane operator $>$ will then be activated. However, only one function $<$ To store materials and other resources $>$ and $<$ To transport items for their assembly or dismantling on site $>$ will be activated and, in it, the function <To coordinate with the crane operator $>$ will be activated as control.

Table 5. Analysis of function couplings up and downstream relating to transport of materials, resources and items by the tower crane 
The function "order the concrete", as seen in Figure 1, also has its output connected to another function "decide what to transport with the tower crane" in terms of control. Therefore, the way in which the crane is to be used will be influenced by the date on which all work must be completed. At the beginning of this section, it was stated that the variability of this function was also of special interest in terms of achieving the desired result. The couplings will therefore be analysed in more detail.

In this context, the function "decide what to transport with the tower crane" is coupled with many other functions on a second level downstream, as shown in Table 5. The crane facilitates the availability of resources to perform different activities at the site and it is used for the assembly of different items like safety frames or nets. In theory, or rather, in accordance with work-as-imaged, the supervisor should decide which items to transport, either for storage or on-site assembly or dismantling. In practice, that is, in accordance with work-as-done, the supervisor gives instructions to the crane operator but the operator is responsible for making decisions regarding everyday work. The operator is subject to the demands of both formwork and steel worker teams working simultaneously at the site, as well as personnel responsible for the assembly of collective or individual protections. If materials and items used to perform their work such as formwork moulds, slab formwork elements, frames, steel bars, safety nets, etc. are not available, other functions cannot be started because they need these resources for this purpose. Consequently, this would cause delays to the performance of the work. This is why decisions made by the crane operator play an essential role and can significantly increase the variability spread through the system as well as stress, workloads and labour disputes. On this subject, a worker said: "The crane is the cancer of a construction site when there are many people. The crane, for example, this crane there, cannot supply everything. And now, thank God, the bricklayers have not started working yet. If formwork operators and bricklayers work at the same time it is impossible. You have to be fighting all day. That is, there is no shift or anything [...] Usually, the crane operator is the one who must organize himself and know what has the most priority". So, if the operator fails to make a precise and timely decision about what to transport with the tower crane, other construction tasks cannot be performed and will await the arrival of materials. This could cause conflicts and it is sometimes necessary to call the supervisor to prevent the situation from becoming even more complicated. A worker also said that a few years ago, when the construction sector was at its peak before the economic crisis, crane operators received bribes from subcontract workers to give priority to their needs in terms of crane availability. It is important to clarify that this statement is based on testimonials of workers and they said that this no longer occurs due to the fact that wages in the construction sector had dropped considerably. However, it is important to ensure that this does not occur or is not repeated if it has already occurred. This behaviour is not compatible with the resilient performance of the construction work.

As mentioned previously, we must add to this the fact that the function "decide what to transport with the tower crane" is coupled upstream with the function "order the concrete". The latter can produce variability that is spread downstream along with the variability of the former by the output of the function "decide what to transport with the tower crane". The variability therefore encounters a path to be spread and increased by the system. This can develop into lack of precision at outputs of other functions downstream, or rather, in the performance of other formwork or steelwork tasks. All of this is dangerous because it could also cause lack of coordination with the crane operator or falling of materials that are not properly secured before transport. 
Finally, the third aspect of interest mentioned at the beginning of this section remains to be addressed. It referred to a group of functions shown in Table 6 that are related to the assembly of collective and individual protections. These functions are aimed at guaranteeing the safety of workers at the site while performing their work. The outputs of these functions are a prerequisite for others relating to work on structures. In conditions of high pressure and workloads, these prerequisites might not be complied with before a function is activated. This causes work to be performed without the necessary protective measures. The vertical nets on the façade could even endanger passers-by not working at the site due to objects falling when the formwork is being removed. It should be noted that many workers interviewed considered the removal of formwork one of the most dangerous tasks, especially in town centres. This is due to the fact that formwork panels are removed without ladders and are left to fall at random.

\begin{tabular}{|l|l|l|l|}
\hline \multicolumn{1}{|c|}{ Function } & \multicolumn{1}{|c|}{$\begin{array}{c}\text { Output of the } \\
\text { function }\end{array}$} & $\begin{array}{c}\text { Aspect of the } \\
\text { downstream function }\end{array}$ & Downstream function \\
\hline $\begin{array}{l}\text { To assemble safety } \\
\text { lifeline }\end{array}$ & Safety lifeline installed & Precondition & $\begin{array}{l}\text { Decide to start the } \\
\text { assembly of the boards } \\
\text { and risers }\end{array}$ \\
\hline $\begin{array}{l}\text { To assemble safety } \\
\text { nets under slab }\end{array}$ & $\begin{array}{l}\text { Safety nets under slab } \\
\text { installed }\end{array}$ & Precondition & $\begin{array}{l}\text { Decide to start the } \\
\text { assembly of the boards } \\
\text { and risers }\end{array}$ \\
\hline $\begin{array}{l}\text { To assemble nets in the } \\
\text { hole }\end{array}$ & Nets placed in the hole \\
$\begin{array}{l}\text { To assemble handrails } \\
\text { on slab }\end{array}$ & Precondition & $\begin{array}{l}\text { To set out the rebar for } \\
\text { slab }\end{array}$ \\
\hline $\begin{array}{l}\text { To install type V safety } \\
\text { net system }\end{array}$ & $\begin{array}{l}\text { Type V safety net } \\
\text { system installed }\end{array}$ & Precondition & $\begin{array}{l}\text { To set out the rebar for } \\
\text { slab }\end{array}$ \\
\hline $\begin{array}{l}\text { To assemble handrails } \\
\text { on slab }\end{array}$ & $\begin{array}{l}\text { Handrails placed on } \\
\text { slab }\end{array}$ & Precondition & $\begin{array}{l}\text { To disassemble safety } \\
\text { line }\end{array}$ \\
\hline $\begin{array}{l}\text { To assemble vertical } \\
\text { safety nets }\end{array}$ & $\begin{array}{l}\text { Vertical safety nets } \\
\text { placed }\end{array}$ & Precondition & To concrete for \\
\hline
\end{tabular}

Table 6. Analysis of couplings downstream from the functions related to collective individual protections.

There are also other factors that should be taken into consideration. On the one hand, these functions, and other red ones relating to safety, are to be used by a group of workers responsible for assembling and disassembling collective and individual protections. Reference to these and safety personnel will be made below. However, said personnel is limited, making it complicated to follow the changing rate of the work performed at the site. It is normal for changes to be made to work plans and that tasks other than those scheduled are often performed instead. This is how delays caused by other tasks that cannot be performed due to lack of resources are buffered. However, safety personnel should outpace the start of work at the site so that all collective or individual protections are installed beforehand. This is often complicated, either because they are not notified of the changes made to the plans or due to lack of manpower or materials. On the other hand, there is an added difficulty due to the fact that some workers disassemble the collective protections to perform their work and do not replace them, as mentioned above. This means that the appropriate conditions necessary for workers to work in a safe working environment are not always provided. 


\subsection{Step 4: Consequences of the analysis}

The key points found as a result of the FRAM analysis of the work performed in the construction of concrete building structures are mentioned below.

- The construction health and safety plan is rarely used

The "work-as-done" analysis showed that the health and safety plan that incorporates risk assessments, produced at the start of the project, is almost never used in the day-to-day work routine of the case study sites. In fact, there is no function or aspect in the FRAM model regarding the performance of daily construction work that mentions this. It should also be noted that workers interviewed were expressly asked about this and they themselves and safety personnel confirmed it. According to the law, the health and safety plan is the key to proper performance and safety and health management in construction site. Nevertheless, in practice, the plan is considered by some as a simple administrative requirement to start construction work. This difference between "wok-as-imagined" and "work-as-done" should be reconciled. For this, a realistic and useful plan for workers should be developed.

\section{- Organisational pressure affects safety}

As mentioned above in the results of the identification of variability, the majority of functions appearing in the FRAM model are human actions. Therefore, they are performed directly by workers that make use of their skills, knowledge and experience to adopt strategies to enable them to face variability and achieve resilient performance. Nevertheless, in general and based on the interviews conducted to collect data prior to the preparation of the model, some workers give priority to effectiveness over thoroughness and set aside safety to finish the work on time if necessary. These workers had certified safety training, although it is important to note that its effectiveness is unknown. Despite that, some workers pointed out that they may be encouraged to take risks in order to achieve production goals due to things such as organizational pressure along with pressure from deadlines and workloads. On this subject, a worker said: On this subject, a worker said: "There are two problems: either I'm fired for safety reasons, or my boss fires me. So you say, look at the pros and cons [...] if I'm fired for safety reasons, my boss can send me to another site, but if my boss fires me, I'll be unemployed, because there aren't any more construction projects. Do you understand what I'm saying?"

- Delivery of the concrete and crane operations are key factors due to their influence on variability

The addition of variability has emphasised the importance of determining the delivery date of the concrete and work using the crane. In the first case, scheduling the date for the delivery of the concrete increases work pressure and pace to meet the deadline, which means that workers have to strike a balance between efficiency and thoroughness, and thoroughness is usually sacrificed to achieve efficiency that 
allows to obtain an acceptable outcome. In the second case, some workers, amongst whom are crane operators, said in interviews that the crane found it difficult to supply materials and give support to all activities requiring the crane. Both tasks can therefore cause variability to spread and affect the performance of other structure building activities. It is therefore important to design measures to dampen and maintain said variability within acceptable limits.

- Leading indicators focused on everyday work are not used

Companies visited have no leading indicators focused on monitoring daily work and successful operations. Lagging indicators are mainly used for safety management in the companies visited. These companies also have integrated management systems, including safety and health, where they use some leading indicators. However, these indicators are not real time or close to it, but quite the opposite, or rather, there is a significant time lag between the time when the information is collected, analysed and results obtained. Therefore, this information cannot detect deviations or signs that help to anticipate shortcomings in the performance of the work. Neither are workers supplied with this information in person.

These defects must be improved to achieve resilient management of performance variability and to dampen it when necessary. It is therefore advisable to design specific action plans to maintain said variability within acceptable performance limits. The main lines of action proposed can be summed up as follows:

- Improvement of construction health and safety plans to contribute to resilient performance.

- Improvement of the organisational safety culture by strengthening resilience.

- In-depth analysis of decision-making and everyday performance of crane operators and the choice of date of receipt of the concrete.

- Development of leading indicators focused on the monitoring of everyday work and successful operations.

\section{Discussion}

In line with the conclusions of other preliminary studies (e.g. de Vries, 2017; Praetorius et al., 2015; Raben et al., 2018b), this research reveals its potential for providing a different perspective on the performance of organisations, focusing on aspects that until now had been undervalued with the methodologies usually implemented (Smith et al., 2017). The analysis carried out in the present study has been focused from the SafetyII perspective, so the objective was not focused on finding potential failures or things that could go wrong, but rather was focused on understanding how everyday success is achieved in the execution of structure construction activities. In this way, this study 
contributes to the improvement of the knowledge of these activities from the point of view of variability and its propagation through the system. For this, the results do not indicate risks or hazards that must be controlled to avoid failure, but the results indicate which functions or tasks of the system have greater variability and how this variability could spread through the couplings and affect other functions of the system. Therefore, once these tasks with potential variability are known, it is important to develop measures or strategies that support the performance of workers who must carry out these tasks to improve their abilities for resilient performance that allow them to anticipate, control and dampen the variability. This will favour daily success and prevent the occurrence of functional resonance.

Specifically, in relation to structure construction activities, the results obtained reveal the impact on variability of decision-making in the organization of the work performed by the crane and the determination of the date of delivery of the concrete. More frequent conclusions are also reached such as the secondary role to which collective protections are often relegated (Rubio-Romero et al., 2013; Saurin et al., 2005) due to pressure and workloads, disregard for the health and safety plan that should be the centre of occupational safety management and the predominant use of lagging indicators in construction activities (Hinze et al., 2013).

In addition, during the interviews, it was found that directly asking employees working at the site, or rather, people at the sharp end, makes them feel important when voicing their opinions, resulting in them being more open. According to Kaya et al. (2018), this openness of the participants improved the understanding of the non-linear behaviour of the activities of building structures as a complex system.

This is how the FRAM analysis helps to encourage the involvement of workers in the performance management process by highlighting their role in the organization. In turn, it reduces the gap between the perspective of those at the top of the hierarchical pyramid, such as directors, engineers, managers and even consultants, and a much more realistic view of how the organisation operates. This can be used as valuable information for improving safety management and developing more effective guidelines and procedures.

Another benefit of the FRAM analysis is that its application to safety management in complex socio-technical systems goes beyond the development of a model that provides a new understanding of the performance of the work. In line with the results of other authors (e.g. Belmonte et al., 2011; Carvalho, 2011; Pickup et al., 2017; Raben et al., 2018a; Ross et al., 2018; Smith et al., 2017), this paper shows the potential of the FRAM analysis as a starting point to establish measures and lines of action so that organisations can improve resilient performance by focusing on Safety-II.

As for the disadvantages of the FRAM in its application in the modelling of complex sociotechnical systems, two aspects stand out. On the one hand, the difficulty in analysing variability, both external and internal as well as upstream and downstream, especially when the purpose of the analysis is prospective and the number of functions comprising the system model is high. The output of each function can therefore be influenced by different sources of endogenous and exogenous variability that can cause diverse effects in the performance of the function. In addition, there is a large number of couplings between functions that generates a multitude of possible paths for the spreading of 
variability. The result is a complicated network of possible scenarios or instantiations.

On the other hand, there is some difficulty in the analysis of variability (Patriarca et al., 2017) that can only be mitigated by experimental modelling with this method and verifying the results with workers involved in the everyday work, who are an invaluable source of knowledge on the performance of the system. In line with this, different studies that have been carried out to facilitate their practical application combine FRAM with other methods (Pardo-Ferreira et al., 2019), although none of them has been consolidated as a widely accepted solution.

Despite this, FRAM is a relatively young method that since its birth (Hollnagel, 2012) has been used to analyse tasks and improve the understanding of the functioning of complex systems. Thus, it has been applied and accepted in different sectors highlighting health care (e.g. Clay-Williams et al., 2015, Pickup et al., 2017) and other sectors such as aeronautics (e.g. Carvalho, 2011; Herrera \& Woltjer, 2010), nuclear (e.g. Hollnagel \& Fujita, 2013; Macchi et al., 2012) or maritime (e.g. De Vries, 2017; Praetorius et al., 2015). Therefore, we believe that the approach used in this study is novel in the activities of building structures and we hope that it will serve as a basis for developing a new approach to safety in the construction sector.

\section{Future research}

The future lines of research that emerge from this study are aimed at advancing the application of Safety-II and RE in the construction sector. Specifically, more in-depth research should be carried out on previously proposed lines of action. It is therefore considered necessary to discover how the content and use of health and safety plans could be improved based on the precepts of RE; study how the improvement of resilient performance can influence the organisation's safety culture; analyse work done by the crane to determine its actual performance through the application of FRAM or other methods; analyse the criteria for scheduling the delivery date of the concrete and its impact on performance; and the development of leading indicators from the proposed FRAM model.

\section{Conclusions}

This study has focused on analysing activities involved in concrete frame construction from a systemic non-linear point-of-view based on the application of FRAM. The results of this study highlight the importance of determining the date of delivery of the concrete, transport of materials and items with the crane and the assembly of collective and individual protections due to their impact on variability and therefore on resilient management. The results also reflect the need to improve the safety culture at all levels, to use safety and health plans as a facilitator of occupational safety management and to develop leading indicators for daily work routines. 
These results present a potential application in organisations intervening in construction work because they allow addressing safety from a different approach to the one that has been taken so far. The results show activities where the resilient performance must be strengthened to continue achieving success daily. In that way, safety management in construction works could be improved from a perspective based on things that go well. However, this requires a remarkable effort by all companies involved in the construction work to face the challenge of transforming their vision of safety, evolving from Safety-I to Safety-II.

For companies that choose to implement this proactive safety vision, the research presented here may be a foothold for starting the transition to Safety-II through the implementation of FRAM. Specifically, the results of this study can be applied by the companies involved in the construction works to improve the understanding of the actual performance of structure building activities and to define objectives and measures to achieve resilient occupational safety management.

Finally, it should be noted that the FRAM model provides an in-depth and systematic analysis of a project's daily performance, highlighting issues that, until now, had been undervalued. This method has great potential as a tool for analysing and understanding complex systems, such as construction works. Therefore, we hope that further studies will be developed to exploit the potential offered by its application to safety management, either by combining it with other methods, directly applying its results to safety management or applying it to the analysis of operations and systems as well as accidents and incidents.

\section{Acknowledgements}

We wish to thank the Spanish Ministry of Economy and Competitiveness for financing project BIA2016-79270-P. It is also important to acknowledge the support given to the Universidad de Málaga and the construction companies that have participated in this investigation allowing for data collection.

\section{References}

Albery, S., Borys, D., Tepe, S., 2016. Advantages for risk assessment: Evaluating learnings from question sets inspired by the FRAM and the risk matrix in a manufacturing environment. Safety Science 89, 180-189. https://doi.org/10.1016/j.ssci.2016.06.005

Badham, R., Clegg, C., 2000. Sociotechnical Theory. Handbook of Ergonomics. W. Karwowski. New York, John Wiley.

Baxter, G., Sommerville, I., 2011. Socio-technical systems: From design methods to systems engineering. Interact Comput 23, 4-17. https://doi.org/10.1016/j.intcom.2010.07.003

Belmonte, F., Schoen, W., Heurley, L., Capel, R., 2011. Interdisciplinary safety analysis of complex socio-technological systems based on the functional resonance accident model: An application to railway traffic supervision. Reliability Engineering \& System Safety 96, 237-249. https://doi.org/10.1016/j.ress.2010.09.006 
Bilir, S., Gürcanli, G.E., 2018. A Method For Determination of Accident Probability in Construction Industry. Teknik Dergi 29.

Carvalho, P.V.R., 2011. The use of Functional Resonance Analysis Method (FRAM) in a mid-air collision to understand some characteristics of the air traffic management system resilience. Reliability Engineering \& System Safety 96, 1482-1498. https://doi.org/10.1016/j.ress.2011.05.009

Clay-Williams, R., Hounsgaard, J., Hollnagel, E., 2015. Where the rubber meets the road: using FRAM to align work-as-imagined with work-as-done when implementing clinical guidelines. Implementation Science 10, 125. https://doi.org/10.1186/s13012-015-0317-y

de Vries, L., 2017. Work as Done? Understanding the Practice of Sociotechnical Work in the Maritime Domain. Journal of Cognitive Engineering and Decision Making 11, 270-295. https://doi.org/10.1177/1555343417707664

Eurostat, 2018. Accidents at work statistics [WWW Document]. URL https://ec.europa.eu/eurostat/statisticsexplained/index.php/Accidents_at_work_statistics (accessed 8.23.18).

Gibb, A.G.F., Finneran, A.M., Cheyne, A., Dainty, A.R.J., Glover, J., Morgan, J., Fray, M., Waterson, P., Bust, P.D., Haslam, R.A., Hartley, R., Pink, S., 2016. Occupational Safety and Health in Networked Organisations. Institution of Occupational Safety and Health (IOSH).

Haddad, A.N., Rosa, L.V., 2015. Construction sustainability evaluation using AHP and FRAM methods, in: IIE Annual Conference. Proceedings. Institute of Industrial and Systems Engineers (IISE), p. 556.

Hallowell, M.R., Gambatese, J.A., 2009. Activity-Based Safety Risk Quantification for Concrete Formwork Construction. Journal of Construction Engineering and Management 135, 990-998. https://doi.org/10.1061/(ASCE)CO.19437862.0000071

Harvey, E.J., Waterson, P., Dainty, A.R.J., 2016. Applying HRO and resilience engineering to construction: Barriers and opportunities. Safety Science. https://doi.org/10.1016/J.SSCI.2016.08.019

Herrera, I.A. \& Woltjer, R., 2010. Comparing a multi-linear (STEP) and systemic (FRAM) method for accident analysis. Reliability Engineering and System Safety 95, 1269-1275. https://doi.org/10.1016/j.ress.2010.06.003

Hinze, J., Thurman, S., Wehle, A., 2013. Leading indicators of construction safety performance. Safety Science 23-28. https://doi.org/10.1016/J.SSCI.2012.05.016

Hollnagel, E., 2014. Safety-I and Safety-II: The Past and Future of Safety Management. Ashgate Publishing, Ltd.

Hollnagel, E., 2012. FRAM: The Functional Resonance Analysis Method: Modelling Complex Socio-technical Systems. CRC Press.

Hollnagel, E., 2009. The ETTO principle: efficiency-thoroughness trade-off: why things that go right sometimes go wrong. Ahsgate.

Hollnagel, E., Hounsgaard, J., Colligan, L., Center for Kvalitet (Region Syddanmark), 2014. FRAM - the Functional Resonance Analysis Method: a handbook for the practical use of the method. Centre for Quality, Region of Southern Denmark, Middelfart.

Hollnagel, E. \& Fujita, Y., 2013. The Fukushima disaster-systemic failures as the lack of resilience. Nuclear Engineering and Technology 45, 13-20. https://doi.org/10.5516/NET.03.2011.078

INSSBT, 2017. Informe anual de accidentes de trabajo en España 2016. Instituto Nacional de Seguridad, Salud y Bienestar en el Trabajo, Madrid.

Kaya, G. K., Ovali, H. F., Ozturk, F., 2019. Using the functional resonance analysis method on the drug administration process to assess performance 
variability. Safety

Science, 118,

835-840.

https://doi.org/10.1016/j.ssci.2019.06.020

López-Arquillos, A., Rubio-Romero, J.C., Gibb, A., 2015. Accident data study of concrete construction companies' similarities and differences between qualified and nonqualified workers in Spain. International Journal of Occupational Safety and Ergonomics 21, 486-492. https://doi.org/10.1080/10803548.2015.1085750

Macchi, L., Oedewald, P., Rø Eitrheim, M.H. \& Axelsson, C., 2012. Understanding maintenance activities in a macrocognitive work system. Presented at the ACM International Conference Proceeding Series, pp. 52-57. https://doi.org/10.1145/2448136.2448147

OSHA, 2018. Commonly Used Statistics [WWW Document]. URL https://www.osha.gov/oshstats/commonstats.html (accessed 8.23.18).

Pardo-Ferreira, M.C., Martínez-Rojas, M., Salguero-Caparros, F., Rubio-Romero, J.C., 2019. Evolution of the Functional Resonance Analysis Method (FRAM) through the combination with other methods. Dirección y Organización, 68, 41-50.

Patriarca, R., Bergström, J., Di Gravio, G., 2017. Defining the functional resonance analysis space: Combining Abstraction Hierarchy and FRAM. Reliability Engineering \& System Safety 165, 34-46. https://doi.org/10.1016/j.ress.2017.03.032

Pickup, L., Atkinson, S., Hollnagel, E., Bowie, P., Gray, S., Rawlinson, S., Forrester, K., 2017. Blood sampling - Two sides to the story. Applied Ergonomics 59, 234-242. https://doi.org/10.1016/j.apergo.2016.08.027

Pillay, M., 2017. Resilience Engineering: An Integrative Review of Fundamental Concepts and Directions for Future Research in Safety Management. Open Journal of Safety Science and Technology 07, 129-160. https://doi.org/10.4236/ojsst.2017.74012

Praetorius, G., Hollnagel, E., Dahlman, J., 2015. Modelling Vessel Traffic Service to understand resilience in everyday operations. Reliability Engineering \& System Safety 141, 10-21. https://doi.org/10.1016/j.ress.2015.03.020

Raben, D.C., Bogh, S.B., Viskum, B., Mikkelsen, K.L., Hollnagel, E., 2018a. Learn from what goes right: A demonstration of a new systematic method for identification of leading indicators in healthcare. Reliability Engineering \& System Safety 169, 187-198. https://doi.org/10.1016/j.ress.2017.08.019

Raben, D.C., Viskum, B., Mikkelsen, K.L., Hounsgaard, J., Bogh, S.B., Hollnagel, E., 2018b. Application of a non-linear model to understand healthcare processes: using the functional resonance analysis method on a case study of the early detection of sepsis. Reliability Engineering \& System Safety 177, 1-11. https://doi.org/10.1016/j.ress.2018.04.023

Righi, A.W., Saurin, T.A., Wachs, P., 2015. A systematic literature review of resilience engineering: Research areas and a research agenda proposal. Reliability Engineering \& System Safety 141, 142-152. https://doi.org/10.1016/j.ress.2015.03.007

Rosa, L.V., Franca, J.E.M., Haddad, A.N., Carvalho, P.V.R., 2017. A Resilience Engineering Approach for Sustainable Safety in Green Construction. Journal of Sustainable Development of Energy, Water and Environment Systems 5, 480495. https://doi.org/10.13044/j.sdewes.d5.0174

Rosa, L.V., Haddad, A.N., de Carvalho, P.V.R., 2015. Assessing risk in sustainable construction using the Functional Resonance Analysis Method (FRAM). Cognition, Technology \& Work 17, 559-573. https://doi.org/10.1007/s10111-0150337-z

Ross, A., Sherriff, A., Kidd, J., Gnich, W., Anderson, J., Deas, L., Macpherson, L., 2018. A systems approach using the functional resonance analysis method to support 
fluoride varnish application for children attending general dental practice. Applied Ergonomics 68, 294-303. https://doi.org/10.1016/j.apergo.2017.12.005

Rubio-Romero, J.C., Carmen Rubio Gámez, M., Carrillo-Castrillo, J.A., 2013. Analysis of the safety conditions of scaffolding on construction sites. Safety Science 55, 160-164. https://doi.org/10.1016/j.ssci.2013.01.006

Rubio-Romero, J.C., Pardo-Ferreira, M.C., Rojas, M.M., López-Arquillos, A., SuarezCebador, M., 2019. Resilience Engineering: Concepts of the New Paradigm, in: Engineering Digital Transformation. Springer, pp. 133-140.

Saurin, T.A., 2016. The FRAM as a tool for modelling variability propagation in lean construction, in: 24th Ann. Conf. of the Int'l. Group for Lean Construction. Boston, MA, USA, p. Sect. 11 pp. 3-12.

Saurin, T.A., Famá, C.C., Formoso, C.T., 2013. Principles for designing health and safety performance measurement systems: insights from resilience engineering. Production 23, 387-401. https://doi.org/10.1590/S0103-65132012005000072

Saurin, T.A., Formoso, C.T., Cambraia, F.B., 2008. An analysis of construction safety best practices from a cognitive systems engineering perspective. Safety Science 46, 1169-1183. https://doi.org/10.1016/J.SSCI.2007.07.007

Saurin, T.A., Formoso, C.T., Cambraia, F.B., Howell, G., 2005. A Cognitive Systems Engineering Perspective of Construction Safety. 13th International Group for Lean Construction Conference: Proceedings 521.

Saurin, T.A., Formoso, C.T., Famá, C., 2014. Criteria for assessing safety performance measurement systems: insights from resilience engineering, in: Resilience Engineering in Practice: Becoming Resilient. Ashgate, pp. 63-78.

Saurin, T.A., Sanches, R.C., 2014. Lean construction and resilience engineering: Complementary perspectives of variability. Presented at the 22nd Annual Conference of the International Group for Lean Construction: Understanding and Improving Project Based Production, IGLC 2014, pp. 61-71.

Schafer, D., Abdelhamid, T.S., Mitropoulos, P., Mrozowski, T., 2009. Resilience engineering: A new approach for safety managment, in: Building a Sustainable Future - Proceedings of the 2009 Construction Research Congress. pp. 766-775. https://doi.org/10.1061/41020(339)78

Smith, D., Veitch, B., Khan, F., Taylor, R., 2017. Understanding industrial safety: Comparing Fault tree, Bayesian network, and FRAM approaches. Journal of Loss Prevention in the Process Industries 45, 88-101. https://doi.org/10.1016/j.jlp.2016.11.016

Studic, M., 2015. Developing a framework for Total Apron Safety Management PhD. Imperial College London.

Sujan, M.A., Huang, H., Braithwaite, J., 2017. Learning from incidents in health care: Critique from a Safety-II perspective. Safety Science, Learning from Incidents 99, 115-121. https://doi.org/10.1016/j.ssci.2016.08.005

Von Buren, H.F., 2013. Análise de acidentes com guindastes móveis utilizando o método FRAM (Functional Resonance Analysis Method) (MSc Thesis). Universidade Federal do Rio de Janeiro, Rio de Janeiro.

Woods, D.D., Hollnagel, E., 2006. Prologue: resilience engineering concepts, in: Resilience Engineering: Concepts and Precepts. Ashgate, pp. 13-18. 